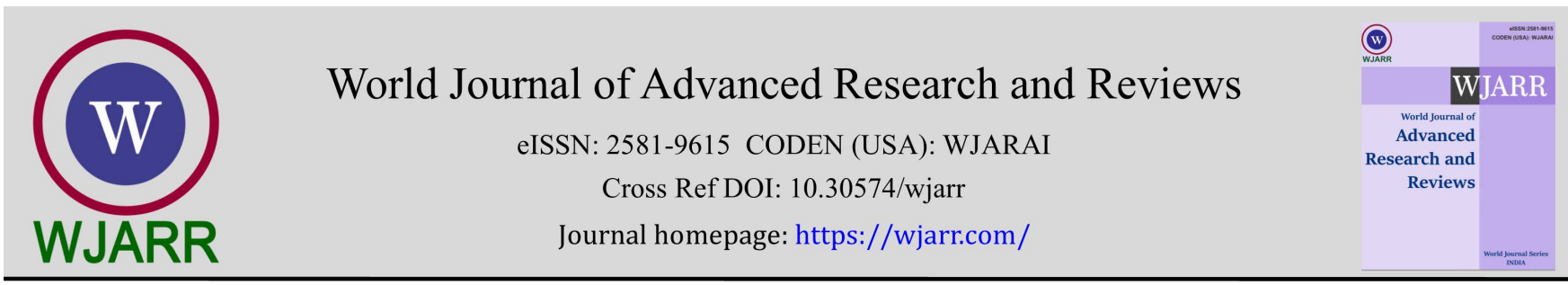

(REVIEW ARTICLE)

Check for updates

\title{
Street food as potential sources of covid-19 disease propagation in central and West Africa: A short review
}

\author{
Christian Tétédé Rodrigue Konfo 1, 2, *, Alain Yaya Koudoro 2, Yénoukounmè Euloge Kpoclou 1, Fowe \\ Michelle Carole Djouhou ${ }^{3}$, Félicien Avlessi ${ }^{2}$, Edwige Dahouenon-Ahoussi ${ }^{2}$ and Dominique Sohounhloue ${ }^{2}$ \\ ${ }^{1}$ National University of Agriculture, Schools of Science and Techniques for Preservation and Processing of Agricultural \\ Products. \\ 2 University of Abomey-Calavi, Polytechnic School of Abomey-Calavi, Laboratory of Study and Research in Applied \\ Chemistry, R. Benin. \\ 3 University of Yaoundé I, Faculty of Science, Department of Biochemistry, Laboratory for Food Science and Metabolism, \\ Yaoundé, Cameroon.
}

World Journal of Advanced Research and Reviews, 2021, 10(02), 014-023

Publication history: Received on 14 December 2020; revised on 21 April 2021; accepted on 25 April 2021

Article DOI: https://doi.org/10.30574/wjarr.2021.10.2.0164

\begin{abstract}
In December 2019, a local pneumonia outbreak of initially unknown cause was detected in Wuhan (Hubei, China) and was quickly determined to be caused by a novel coronavirus, named severe acute respiratory syndrome coronavirus 2 (SARS-CoV-2). This pandemic spread very quickly around the world and has begun its proliferation in Africa. Respect of hygienic rules is one of the best preventive methods. This study explored street ready to eat foods as potential vehicle of human contamination with SARSCoV-2. For this, a bibliographic search was carried out from March 15 to December 7,2020 . From the results, it is well known that the transmission of the coronavirus by direct digestive route is ruled out for now. However, some studies are trying to demonstrate gastrointestinal manifestations and potential fecal-oral transmission of the virus. So ready to eat foods such as fruits and vegetables, bread, chips, donut, gari, snacks, homemade yogurt, cake, fried yam, roasted products, kilichi, ... etc. should get particular attention due to potential risk of contamination by manipulators during conditioning and packaging, to prevent the proliferation of the virus. It then becomes urgent to engage the population's attention concerning what and where they eat.
\end{abstract}

Keywords: SARSCoV-2; Covid-19 diseases; Pandemic; Street foods; Africa

\section{Introduction}

The current outbreak of the novel coronavirus SARSCoV-2 (coronavirus disease 2019; previously 2019- nCoV), epicentred in Hubei Province of the People's Republic of China, has spread to many other countries. On January 30, 2020, the WHO Emergency Committee declared a global health emergency based on growing case notification rates in China and international locations [1]. Although the outbreak is likely to have started from a zoonotic transmission event associated with a large seafood market that also traded in live wild animals, it soon became clear that efficient personto-person transmission was also occurring [2]. According to Nature, the spread of coronavirus disease 2019 (COVID19) is becoming unstoppable and has already reached the necessary epidemiological criteria for it to be declared a pandemic, having infected more than 100000 people in 100 countries [3]. At a press conference in Geneva on March 2020, the Director-General of WHO, Tedros Adhanom Ghebreyesus, warned: "The best advice to give to Africa is to

\footnotetext{
${ }^{*}$ Corresponding author: Christian Tétédé Rodrigue Konfo

National University of Agriculture, Schools of Science and Techniques for Preservation and Processing of Agricultural Products, Food and Bioresources and Human Nutrition Science and Technology Laboratory. 
prepare for the worst and to prepare today. To a question of a Rwandan journalist, the head of the WHO said that while the incidence of the disease is low, the African continent should "prepare for the worst."

Initially spared, the virus now spreads across the African continent. Poverty, inequality, difficulties in accessing basic infrastructure and means of payment, the abundant use of cash in transactions, collective catering and in particular street food are likely to increase the speed of virus spread in this continent [4].

Most street foods are ready-to-eat foods prepared and commercialized in streets and/or in similar public places. Due to its low cost and convenience, street food is consumed each day by thousands of people in Africa [5]. They differ greatly from one country or culture to another. Street foods provide a source of readily available, inexpensive and nutritional meals, while providing a source of income for sellers [6].

Sellers often use stands and carts that are of crude and inefficient construction, running water not easily accessible, and hand and dish washing performed in the same bucket, sometimes without soap. Wastewater is usually discarded in streets, and garbage is discarded nearby, providing attraction, food and harborage for insects and rodents. In many cases, toilets are not available, thus forcing sellers to eliminate their body wastes in nearby areas and to return to their shop sites without washing hands [7].

\section{Methodology}

TA bibliographic search was carried out from March 15 to April 7, 2020. The following terms were particularly searched, always in combination with "SARS-CoV-2", "corona virus", "COVID 19", "mechanism of infection", "surfaces" and "oral infection". We also looked for the term "street food" in combination with "Africa", "typology", "ready to eat", "microbiological quality". With regard to "SARS-CoV-2", only articles published between December 2019 and December 2020 were considered. In relation to street foods, research was extended to 1993, since several types of considered food have been little studied.

\section{Results and discussion}

\subsection{Description of SARS-COV-2}

SARS-CoV-2 is a coronavirus and belongs to the $\beta$-coronavirus cluster. COVID-19 is the third known zoonotic coronavirus disease after SARS and the Middle East respiratory syndrome (MERS). SARS-CoV-2 is a coronavirus and belongs to the $\beta$-coronavirus luster [8]. COVID-19 is the third known zoonotic coronavirus disease after severe acute respiratory syndrome coronavirus (SARS) and the Middle East respiratory syndrome (MERS). Zhu et al. [9] confirmed that SARS-CoV-2 was a new $\beta$-coronavirus belonging to the subgenus botulinum of Coronaviridae. According to the current data, the early COVID-19 cases were related to the Huanan seafood market. The WHO report claimed that the SARS-CoV-2 could be detected in the environmental samples collected from the seafood market [10].

\subsection{Infection mechanism of SARSCoV-2and possibility of fecal-oral transmission}

\subsubsection{Infection mechanism of SARSCoV-2}

Zhao et al. [11] found that angiotensin-converting enzyme 2 (ACE2) was the receptor for SARS-CoV-2. In the normal human lung, ACE2 is expressed on type I and II alveolar epithelial cells. Among them, $83 \%$ of the type II alveolar cells have ACE2 expression. The binding of SARS-CoV-2 on ACE2 causes an elevated expression of ACE2, which can lead to damages on alveolar cells. Damages to alveolar cells can, in turn, trigger a series of systemic reactions and even death. Wrapp et al. [12] found that the receptor-binding ability of SARS-CoV-2 is 10 to 20 times stronger than that of SARS$\mathrm{CoV}$.

\subsubsection{Hypothesis on fecal-oral transmission}

It has been sufficiently demonstrated that transmission of the corona virus occurs from human to human from the droplets and postlets of infected persons and to date oral transmission is excluded. Nevertheless, a close relationship with infected animals and consumption of food contaminated with biological fluids from individuals carrying the virus could be possible sources of contamination [13-14]. According to $\mathrm{Gu}$ et al. [15], fecal-oral transmission would be plausible. Indeed, amounting evidence from former studies of SARS indicated that the gastrointestinal tract (intestine) tropism of SARS coronavirus (SARS-CoV) was verified by the viral detection in biopsy specimens and stool even in discharged patients, which may partially provide explanations for the gastrointestinal symptoms, potential recurrence 
and transmission of SARS from persistently shedding human as well [16-17]. Moreover, the presence of the virus has already been revealed in the feces and urine samples of bats, as well as in the stool of a small proportion of patients suffering from corona virus and SARS-CoV-2 [18]. Under these conditions, improper handling, storage and preparation of food could facilitate this type of contamination, especially for food that no longer undergoes any heat treatment before consumption because it is well known that the virus is rapidly inactivated in the range high temperatures $\left(50{ }^{\circ} \mathrm{C}\right)[8,9$, $19,20,21,22,23]$. Studies in China have shown that the spread of the virus has probably been facilitated by the preparation and consumption of bat sauce $[24,25,15]$. It is therefore highly desirable that future studies examine this possibility of contamination.

\subsection{Defining street foods}

Street foods are most commonly sold in low- and middle-income countries and the types of commercialized food vary according to socio-economic status of consumers and the food cultural habit of local people [26]. The Food and Agricultural Organization (FAO) of the United Nations defines street foods as ready-to-eat foods and beverages prepared and/or sold in streets and other similar public places [27]. In this study, we focused on ready-to-eat foods, because of the high risk they represent, since they do not undergo any culinary treatment before their consumption.

\subsection{Evidence on microbiological characteristics of street food in Africa}

It is recognized that street food sellers are often poor, uneducated and without knowledge on food handling. Consequently, street foods are perceived to be a major public health risk. The major problem relates to the health safety of these foods, but we can also point out other difficulties, such as those related to sanitation (accumulation of waste in the streets and congestion of sewers). The risk of serious food poisoning associated with street food remains a threat in many countries of the continent where microbiological contamination is one of the major problems. In 1993, the World Health Organization (WHO) undertook a survey in over 100 countries to assess the situation with regard to street food. The survey noted that most countries reported contamination of food (from raw food, infected handlers and inadequately cleaned equipment) and time and temperature appeared to be the major factors contributing to foodborne disease. This was partially due to the fact that infrastructure development was relatively limited, with restricted access to potable water, toilets, refrigeration, washing and waste-disposal facilities. Moreover, registration, training and medical examinations were not among the selected management strategies [28].

The presence of selected foodborne pathogens in street food samples as well as the presence of nonpathogenic $E$. coli (in food and water samples) was also tested in Johannesburg, South Africa. A mean Enterobacteriaceae counts value of 2.0 (60.4) $\log$ CFU/g for food samples and mean coliform counts values of 2.5 (60.3) $\log \mathrm{CFU} / \mathrm{ml}$ and 1.3 (60.3) $\log$ $\mathrm{CFU} / 25 \mathrm{~cm}^{2}$ for water and swab samples respectively, were determined. Mean PC values of 1.6 (60.1) log CFU/g, 1.9 (60.6) $\log \mathrm{CFU} / \mathrm{ml}$, and 1.4 (60.4) $\log \mathrm{CFU} / 25 \mathrm{~cm}^{2}$ were determined for food, water and swab samples, respectively. Bacillus cereus was detected in 22\%, Clostridium perfringens in 16\%, Salmonella spp in 2\%, and E. coli (non- 0157:H1) in $2 \%$ of the 51 food samples. E. coli was found in 14 water samples (78\%) and in 3 food samples (6\%). Campylobacter spp., Listeria monocytogenes, Staphylococcus aureus, Vibrio cholerae, and Yersinia enterocolitica were also tested for in the food samples, but they were not detected [29-30]. Food-borne outbreaks caused by hepatitis A virus are mainly associated with bivalve mollusks, product (soft fruits and leafy greens) and ready-to-eat meals [31].

Dègnon, et al. [7] evaluated the hygienic quality of salad dishes sold in Cotonou (Benin). The results revealed thirteen (13) types of salad dishes. None of the thirty (30) samples analyzed met the microbiological criteria. Table 1 below describes some ready to eat local foods from Africa, potential vectors of SARSCoV-2.

More recently, Asiegbu et al. [32] have come to the conclusion that the microbial quality and safety of ready-to-eat sold in the Johannesburg Metropolis remain a serious public health concern. Indeed, studying hygienic quality of street food sold in Johannesburg Metropolis (South Africa), their result showed that of the 205 ready-to-eat street-vended foods samples, $85.37 \%$ had aerobic growth. The vast majority (78.18\%) of the 110 ready-to-eat SVF samples had Enterobacteriaceae growth. And the prevalence rates of L. monocytogenes, S. aureus, Salmonella spp., and E. coli 015:H7 were $46.36,31.8,21.8$, and $1.8 \%$, respectively.

In short, these studies reveal that the conditions of processing and marketing of street food do not guarantee their good hygienic quality.

According to Baba-Moussa et al. [33] the environment plays a crucial role in the contamination process. Indeed, the stands and improvised structures for the sale of these foods are located along the sidewalks which are the places of sale of its foods. The vendors share the sidewalk with many other street vendors who sell clothes, toys and other items. These facilities are not far from waste water points and garbage. After preparation, the food is placed on tables often on 
the ground and briefly covered near busy streets and is no longer heated before being served. most of the time. We note during the monitoring of the sales operations that the itinerant and semi-fixed sellers do not have enough water for the dishes. In addition, the condition and nature of the packaging used is deplorable and consist of old paper, mold, unsuitable plastic bags, and cement bag papers.

The following photos present, for example, the conditions for processing braised meats at the edges of streets in Cotonou. We note that the mutton meats samples were stored in the open air around the streets (Pictures B, D and E), in an unhealthy environment (Pictures A, C and F). These conditions expose the samples to biological dangers (bacteria, organisms producing toxins, viruses, parasites, etc.).
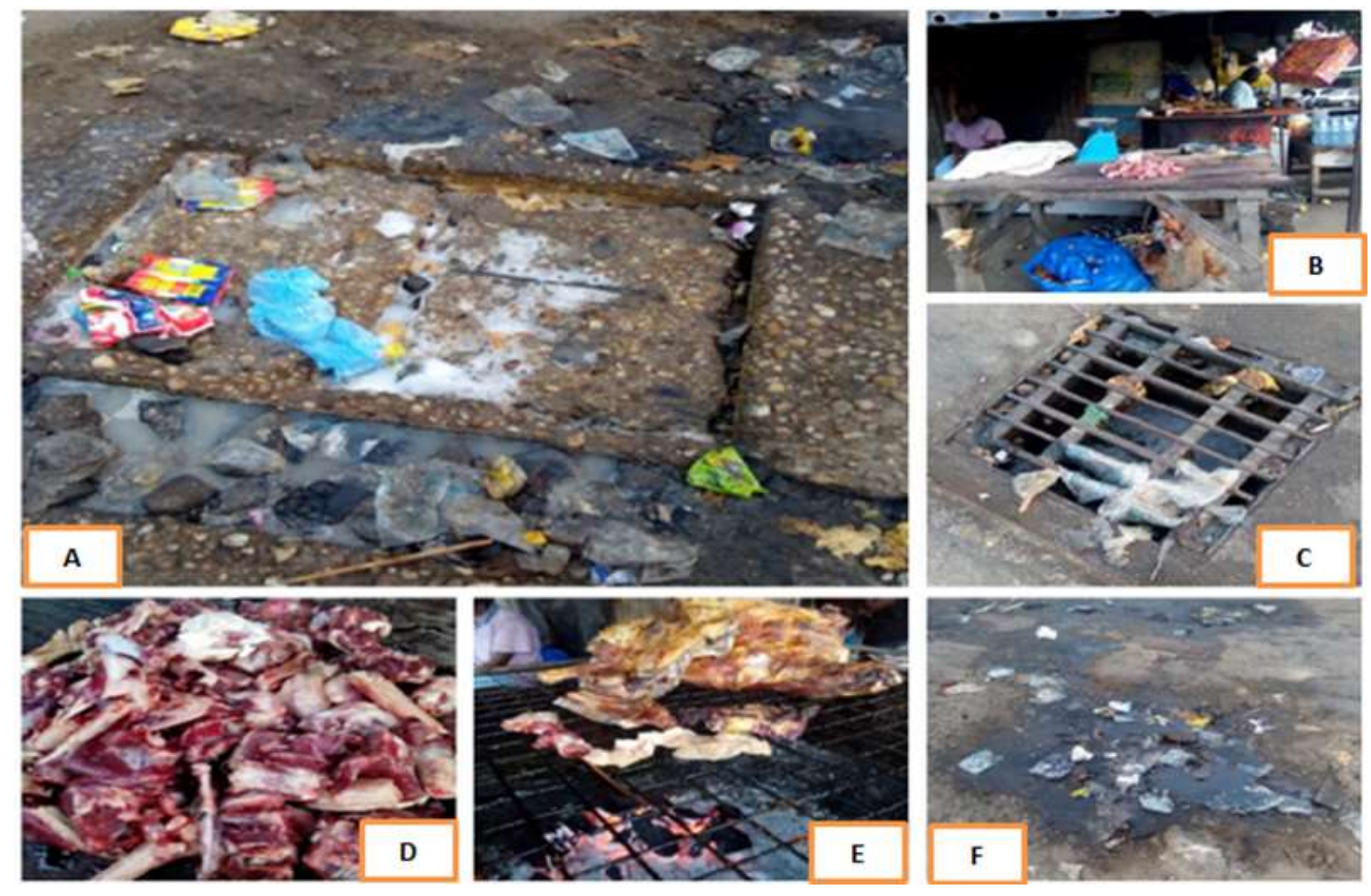

Figure 1 Storage and marketing conditions for cotton or mutton (By Konfo, 2020)

\subsection{SARSCoV-2 characteristics which could facilitate the contamination of street food}

To determine the coronavirus lifetime in the air, researchers used a nebulizer, a device transforming liquid (droplets containing viral particles of Covid-19) into fine particles. These particles were then sprayed using an aerosol in the ambient air and on various surfaces, in order to reproduce saliva projections of a contaminated person who coughs or who sneezes. Results showed viable suspended particles of coronavirus in the air 3 hours after spraying. This means that coronavirus can remain viable and infectious for up to 3 hours in the air [34]. It is well known that "the transmission of the coronavirus by direct digestive route is ruled out" as stated by the National Agency for Food Safety (ANSES) in a press release in March 2020.

In addition, since contamination of an animal is unlikely, the possibility of direct transmission of the virus through food from a contaminated animal has been excluded by experts. In other words, the coronavirus cannot be transmitted by meat or fish, as soon as they are cooked and/or submitted to high temperature before consumption [35]. However, contamination of the packaging of these foods deserves to be taken seriously. According to Kampf et al. [23], human coronaviruses can remain infectious on inanimate surfaces for up to 9 days depending on the surface. However, gastrointestinal manifestations and potential fecal-oral transmission of the virus should be seriously considered [15]. Table 2 shows the lifetime of the virus on different surfaces. 
Table 1 Some street foods for which special attention is required.

\begin{tabular}{|c|c|c|c|c|}
\hline Countries & $\begin{array}{l}\text { Incriminated } \\
\text { street food }\end{array}$ & Brief description & $\begin{array}{l}\text { Commonly used } \\
\text { packaging forms }\end{array}$ & References \\
\hline All Countries & Bread & $\begin{array}{l}\text { Filled and fermented } \\
\text { wheat flour }\end{array}$ & $\begin{array}{l}\text { Plastic bag, paper, } \\
\text { nothing }\end{array}$ & {$[36]$} \\
\hline Benin & Corn bread & $\begin{array}{l}\text { Filled and fermented } \\
\text { maize flour }\end{array}$ & $\begin{array}{l}\text { Plastic bag, paper, } \\
\text { nothing }\end{array}$ & {$[37]$} \\
\hline $\begin{array}{l}\text { Benin, Cameroon, } \\
\text { Congo, Tchad, Gabon }\end{array}$ & Snacks & Roasted maize & $\begin{array}{l}\text { Plastic bag, paper, } \\
\text { maize leaves }\end{array}$ & {$[37]$} \\
\hline $\begin{array}{l}\text { Benin, Cameroon, } \\
\text { Congo, Tchad, Gabon }\end{array}$ & Snacks & Boiled maize & $\begin{array}{l}\text { Plastic bag, paper, } \\
\text { maize leaves }\end{array}$ & {$[37]$} \\
\hline Benin & Snacks & $\begin{array}{l}\text { Fried salty maize based } \\
\text { flat cake in form of small } \\
\text { balls. }\end{array}$ & Plastic bag, paper & {$[37]$} \\
\hline $\begin{array}{l}\text { Benin, Cameroon, } \\
\text { Gabon }\end{array}$ & Snacks & $\begin{array}{l}\text { Boiled or roasted maize } \\
\text { and peanut grains }\end{array}$ & Plastic bag, paper & {$[37]$} \\
\hline Benin & Snacks & $\begin{array}{l}\text { Fried seasoned maize } \\
\text { based flat cake in chain } \\
\text { ball form }\end{array}$ & Plastic bag, paper & {$[37]$} \\
\hline All countries & Snacks & Pop-corn & Plastic bag, paper & {$[37]$} \\
\hline Benin & Snacks & $\begin{array}{l}\text { Fried maize based flat } \\
\text { cake with red oil }\end{array}$ & Plastic bag, paper & {$[37]$} \\
\hline Benin & Snacks & $\begin{array}{l}\text { Fried maize based flat } \\
\text { cake with condiments }\end{array}$ & Plastic bag, paper & {$[37]$} \\
\hline Benin & Snacks & $\begin{array}{l}\text { Pre-cooked, dried and } \\
\text { fried rice grain } \\
\text { consumed with roasted } \\
\text { peanuts }\end{array}$ & Plastic bag, paper & {$[37]$} \\
\hline Benin & Snacks & $\begin{array}{l}\text { Fried spiced maize } \\
\text { based flat cake }\end{array}$ & Plastic bag, paper & {$[37]$} \\
\hline $\begin{array}{l}\text { Benin, Cameroon, } \\
\text { Gabon }\end{array}$ & Snacks & $\begin{array}{l}\text { Roasted maize flour } \\
\text { puff-puff }\end{array}$ & Plastic bag, paper & {$[37]$} \\
\hline Benin & Andu & $\begin{array}{l}\text { Roasted maize flour } \\
\text { balls }\end{array}$ & Plastic bag, paper & {$[37]$} \\
\hline Benin & Akpan & Cereal-based yoghurt & $\begin{array}{l}\text { Plastic bag and } \\
\text { cups }\end{array}$ & {$[37]$} \\
\hline All Countries & $\begin{array}{l}\text { Home-made } \\
\text { yogurt }\end{array}$ & Fermented milk & $\begin{array}{l}\text { Plastic packaging } \\
\text { and cups }\end{array}$ & {$[38]$} \\
\hline $\begin{array}{l}\text { Senegal, Benin, } \\
\text { Cameroon, Tchad }\end{array}$ & Vegetable drink & $\begin{array}{l}\text { Granulated cereals } \\
\text { added to fermented milk }\end{array}$ & $\begin{array}{l}\text { Plastic bag and } \\
\text { cups }\end{array}$ & {$[39]$} \\
\hline $\begin{array}{l}\text { Benin ; Cameroon, } \\
\text { Tchad }\end{array}$ & Cake & $\begin{array}{l}\text { Cowpea donut (puff- } \\
\text { puff) }\end{array}$ & Plastic bag, paper & {$[40]$} \\
\hline All African countries & Wheat donut & Wheat donut (puff-puff) & Plastic bag, paper & {$[41]$} \\
\hline Benin & Fried yam & Fried sliced yam & Plastic bag, paper & {$[42]$} \\
\hline Cameroon & $\begin{array}{l}\text { Fried or roasted } \\
\text { plantain }\end{array}$ & $\begin{array}{l}\text { Fried or roasted } \\
\text { plantain }\end{array}$ & Plastic bag, paper & {$[43]$} \\
\hline Benin & Wheat Chips & Wheat based snacks & Plastic bag, paper & {$[41]$} \\
\hline
\end{tabular}


World Journal of Advanced Research and Reviews, 2021, 10(02), 014-023

\begin{tabular}{|c|c|c|c|c|}
\hline $\begin{array}{l}\text { Benin, Cameroon, } \\
\text { Tchad }\end{array}$ & Peanut pancake & $\begin{array}{l}\text { Partially defatted fried } \\
\text { peanut sticks }\end{array}$ & $\begin{array}{l}\text { Plastic bag, plastic } \\
\text { buckets, paper }\end{array}$ & {$[44]$} \\
\hline $\begin{array}{l}\text { Benin, Cameroon, } \\
\text { Gabon, Ivory Coast, } \\
\text { Tchad }\end{array}$ & Snacks & Boiled peanut & Plastic bag, paper & {$[45]$} \\
\hline Benin, Cameroon & Snacks & Roasted peanuts & Plastic bag, paper & {$[46]$} \\
\hline Benin & Concada & $\begin{array}{l}\text { Caramel coated peanut } \\
\text { in the form of flat balls }\end{array}$ & $\begin{array}{l}\text { Plastic bag, glass } \\
\text { and paper }\end{array}$ & {$[47]$} \\
\hline Benin, Cameroon & Nougat & Peanut and sugar candy & $\begin{array}{l}\text { Plastic bag, glass } \\
\text { and paper }\end{array}$ & {$[48]$} \\
\hline $\begin{array}{l}\text { Ivory Coast, Togo, } \\
\text { Ghana, Nigeria, } \\
\text { Benin, Cameroon }\end{array}$ & Gari & Granular cassava & Plastic bag & $\begin{array}{l}{[49]} \\
{[50]}\end{array}$ \\
\hline $\begin{array}{l}\text { Ivory Coast, Togo, } \\
\text { Ghana, Nigeria, } \\
\text { Benin, Cameroon }\end{array}$ & Pure water & $\begin{array}{l}\text { Sachet-packed drinking } \\
\text { water }\end{array}$ & Plastic bag & $\begin{array}{l}{[51]} \\
{[52]}\end{array}$ \\
\hline All Countries & $\begin{array}{l}\text { Fruits (dates, } \\
\text { Orange, } \\
\text { tangerine, } \\
\text { Watermelons, } \\
\text { banana, } \\
\text { mango...) }\end{array}$ & $\begin{array}{l}\text { Fruits (dates, Orange, } \\
\text { tangerine, Watermelons, } \\
\text { banana, mango...) }\end{array}$ & Plastic bag & {$[53]$} \\
\hline $\begin{array}{l}\text { Benin, Togo, Burkina, } \\
\text { Cameroon }\end{array}$ & Fruit nectar & $\begin{array}{lrr}\begin{array}{l}\text { Boiled water } \\
\text { flavoured } \\
\text { extracts }\end{array} & & \\
\text { with } & \text { fruit } \\
\end{array}$ & $\begin{array}{l}\text { Plastic bag, plastic } \\
\text { bottle }\end{array}$ & {$[54]$} \\
\hline All Countries & $\begin{array}{l}\text { Raw vegetables } \\
\text { (lettuce, carrot } \\
\text {...) }\end{array}$ & Salad, fruit salad & Plastic bowl, bag & [7] \\
\hline $\begin{array}{l}\text { Cameroon, Tchad, } \\
\text { Niger }\end{array}$ & Kilichi & Spiced and dried meat & Plastic bag, paper & {$[55]$} \\
\hline $\begin{array}{l}\text { Cameroon, Tchad, } \\
\text { Senegal, Ivory Coast, } \\
\text { Gabon, Benin }\end{array}$ & $\begin{array}{l}\text { Roasted meat } \\
\text { and fish }\end{array}$ & Roasted meat and fish & Plastic bag, paper & {$[56]$} \\
\hline
\end{tabular}

Table 2 Lifetime of the coronavirus on different surfaces

\begin{tabular}{|l|l|l|l|}
\hline Countries & Type of packaging & $\begin{array}{l}\text { Duration of virus survival } \\
\text { (Hours ) }\end{array}$ & References \\
\hline Canada, United States & Cardboard & 24 & {$[34]$} \\
\hline Canada, United States & Steel can & 48 & {$[34]$} \\
\hline France & Glass & 120 & {$[34]$} \\
\hline \multirow{3}{*}{ United States } & Plastic & $48-72$ & {$[34],[57]$} \\
\hline \multirow{3}{*}{ United States } & Paper & 5 & {$[57]$} \\
\cline { 2 - 5 } & Wood & 2 & {$[57]$} \\
\hline
\end{tabular}




\subsection{Precautions to limit the risks}

To minimize the risks, it is advisable to wash hands after shopping and rinse fruits and vegetables with potable water. An infected person can contaminate food by preparing or handling it with dirty hands, or by exposing it to infectious droplets when coughing and sneezing. These are also basic hygiene rules that should be applied even outside an epidemic period. It is also important to steam vegetables and peel fruits and vegetables as a precaution. By analogy with other known coronaviruses, SARSCoV-2 seems sensitive to cooking temperatures. Thus, a heat treatment at $70^{\circ} \mathrm{C}$ for 4 min (temperature used in collective catering) makes it possible to divide by 10.000 the contamination risk of a food product [35]. In view of all of the above, it is highly recommended to avoid street food, especially ready-to-eat food during a pandemic.

\section{Conclusion}

The spread of severe acute respiratory syndrome coronavirus 2 (SARS-CoV-2) has already taken pandemic proportions, affecting over 100 countries in a matter of weeks. A global response to prepare health systems worldwide is imperative. Although containment measures in China have reduced new cases by more than $90 \%$, this method cannot be fully applied in Africa where living conditions are more difficult. However, SARSCoV-2 is exponentially expanding in Africa and appropriate responses must be implemented. In this study, we focused on street food as a potential source of contamination of this virus in Central and West Africa. It appears that ready-to-eat foods as bread, donuts, cakes, pancakes, fruits, vegetables etc. and their packaging should be particularly avoided during the pandemic period to limit the effects of this virus.

\section{Compliance with ethical standards}

\section{Acknowledgments}

The authors thank deeply all the street vendors associated in this study.

\section{Disclosure of conflict of interest}

The authors agree no conflict of interest.

\section{References}

[1] Velavan TP, Meyer CG. The COVID-19 epidemic. Trop Med Int Health. 2020; 25(3): 278-280.

[2] Li Q, Guan X, Wu P, Wang X, Zhou L, Tong Y, Xing X. Early transmission dynamics in Wuhan, China, of novel coronavirus-infected pneumonia. New England Journal of Medicine. 2020.

[3] Callaway E. Time to use the p-word? Coronavirus enter dangerous new phase. Nature. 2020; 579: 12.

[4] Assoumou-Ella G. Transactions et risque de propagation du COVID-19: une modélisation à partir de la vitesse de circulation de la monnaie au Gabon (Transactions and Risk of Propagation of COVID-19: A Model Based on the Speed of Circulation of Money in Gabon). (March 24, 2020). GAE Working Paper. 2020; (4).

[5] Steyn NP, Labadarios D. Street foods and fast foods: How much do South Africans of different ethnic groups consume?. Ethnicity and Disease. 2011; 21(4): 462.

[6] Mosupye FM, von HOLY A. Microbiological quality and safety of ready-to-eat street-vended foods in Johannesburg, South Africa. Journal of Food Protection. 1999; 62(11): 1278-1284.

[7] Dègnon RG, Konfo CT, Adjou ES, GANIERO EG, Dahouenon-Ahoussi E. Evaluation of the Microbiological Quality of Salad Dishes Served in Cotonou Restaurants (Benin). American Journal of Food Science and Technology. 2018; 6(3): 98-102.

[8] Chen Y, Liu Q, Guo D. Emerging coronaviruses: genome structure, re-plication, and pathogenesis. J Med Virol. 2020; 92: 418-423.

[9] Zhu N, Zhang D, Wang W, et al. A novel coronavirus from patientswith pneumonia in China, 2019. N Engl J Med. 2020; 382: 727-733.

[10] Sun P, Lu X, Xu C, Sun W, Pan B. Understanding of COVID-19 based on current evidence. Journal of medical virology. 2020. 
[11] Zhao Y, Zhao Z, Wang Y, Zhou Y, Ma Y, Zuo W. Single-cell RNA expression profiling of ACE2, the putative receptor of Wuhan 2019-nCov. BioRxiv. 2020.

[12] Wrapp D, Wang, N, Kizzmekia S. Kizzmekia S. Corbett, Goldsmith J. A., Ching-Lin Hsieh, Olubukola Abiona, Graham B.S., McLellan J.S.. Cryo-EM Structure of the SARS-CoV-2 Spike in the Prefusion Conformation, medRxiv. 2020.

[13] Newell DG, Koopmans M, Verhoef L, Duizer E, Aidara-Kane A, Sprong H, Opsteegh M, Langelaar M, Threfall J, Scheutz F, van der Giessen J, Kruse H. Food-borne diseases - the challenges of 20 years ago still persist while new ones continue to emerge. International Journal of Food Microbiology. 2010; 139: S3-S15.

[14] Wang M, Yan M, Xu H, Liang W, Kan B, Zheng B, Chen H, Zheng H, Xu Y, Zhang E, Wang H, Ye J, et al. SARS-CoV infection in a restaurant from palm civet. Emerging Infectious Diseases. 2005; 11: 1860-1865.

[15] Gu J, Han B, Wang J. COVID-19: Gastrointestinal Manifestations and Potential Fecal-Oral Transmission. Gastroenterology. 2020.

[16] Leung WK, To KF, Chan PK, Chan HL, Wu AK, Lee N, Sung JJ. Enteric involvement of severe acute respiratory syndrome-associated coronavirus infection. Gastroenterology. 2003; 125(4), 1011-1017.

[17] Holshue ML, DeBolt C, Lindquist S, Lofy KH, Wiesman J, Bruce H, Diaz G. First case of 2019 novel coronavirus in the United States. New England Journal of Medicine. 2020.

[18] Yeo, C., Kaushal, S., \& Yeo, D. (2020). Enteric involvement of coronaviruses: is faecal-oral transmission of SARSCoV-2 possible?. The lancet Gastroenterology \& hepatology, 5(4), 335-337.

[19] Ding, S., \& Liang, T. J. (2020). Is SARS-CoV-2 also an enteric pathogen with potential Fecal-Oral transmission: a COVID-19 virological and clinical review. Gastroenterology.

[20] Bui, D., Brown, H. E., Harris, R. B., \& Oren, E. (2016). Serologic evidence for fecal-oral transmission of Helicobacter pylori. The American journal of tropical medicine and hygiene, 94(1), 82-88.

[21] Bertrand I, Schijven JF, Sánchez G, Wyn-Jones P, Ottoson J, Morin T, Muscillo M, Verani M, Nasser A, de Roda Husman AM, Myrmel M, Sellwood J, et al. The Downloaded from impact of temperature on the inactivation of enteric viruses in food and water: a review. Journal of Applied Microbiology. 2012; 112: 1059-1074.

[22] Casanova LM, Jeon S, Rutala WA, Weber DJ, Sobsey MD. Effects of air temperature and relative humidity on coronavirus survival on surfaces. Applied Environmental Microbiology. 2010; 76: 2712-2717.

[23] Kampf G, Todt D, Pfaender S, Steinmann E. Persistence of coronaviruses on inanimate surfaces and its inactivation with biocidal agents. Journal of Hospital Infection. 2020; 104: 246-251.

[24] Verma S, Dixit A. Relation between humans and animals at national and international level with reference to wildlife. Our Heritage. 2020; 68: 3853-3862.

[25] Zhou P, Yang XL, Wang XG, Hu B, Zhang L, Zhang W, Si HR, Zhu Y, Li B, Huang CL, Chen HD, Chen J, et al. A pneumonia outbreak associated with a new coronavirus of probable bat origin. Nature. 2020.

[26] Steyn, N. P., \& Labadarios, D. (2011). Street foods and fast foods: How much do South Africans of different ethnic groups consume?. Ethnicity and Disease, 21(4), 462.

[27] Martins JH. Socio-economic and hygiene features of street food vending in Gauteng. South African Journal of Clinical Nutrition. 2006; 19(1): 18-25.

[28] World Health Organization. Food Safety Issues: Essential Safety Requirements for Street-Vended Foods. Geneva: WHO. 1996.

[29] Mosupye, F. M., \& von HOLY, ALEXANDER. (1999). Microbiological quality and safety of ready-to-eat streetvended foods in Johannesburg, South Africa. Journal of Food Protection, 62(11), 1278-1284.

[30] Adewoye AO, Adewoye SO, Opasola OA. Microbiological examination of sachet water experimentally exposed to sunlight. International Journal of Pure and Applied Sciences and Technology. 2013; 18(1): 36.

[31] Sánchez, G. (2015). Processing strategies to inactivate hepatitis A virus in food products: a critical review. Comprehensive Reviews in Food Science and Food Safety, 14(6), 771-784.

[32] Asiegbu CV, Lebelo SL, Tabit FT. Microbial Quality of Ready-to-Eat Street Vended Food Groups Sold in the Johannesburg Metropolis, South Africa. Journal of food quality and hazards control. 2020. 
[33] Baba-Moussa L, Bokossa YI, Baba-Moussa F, Ahissou H, Adeoti Z, Yehouenou B, Sanni A. Etude des possibilités de contamination des aliments de rues au Bénin: cas de la ville de Cotonou. J. Rech. Sci. Univ. Lomé. 2006; 8: 149156.

[34] Van Doremalen N, Bushmaker T, Morris DH, Holbrook MG, Gamble A, Williamson BN, Lloyd-Smith JO. Aerosol and surface stability of SARS-CoV-2 as compared with SARS-CoV-1. New England Journal of Medicine. 2020.

[35] Gray R. Covid-19 : Quelle est la durée de vie du coronavirus sur les surfaces ? 2020.

[36] Kaimowitz D. Not by bread alone... forests and rural livelihoods in sub-Saharan Africa. In Forests in poverty reduction strategies: capturing the potential. EFI Proceedings. 2003; 47: 45-63.

[37] Houansou G, Guidi C, Chegnimonhan, V, \& Tchibozo, M. A. D. (2019). Typologie et perception des populations sur la qualité organoleptique des casse-croûtes produits à base de céréales dans sept Départements du Bénin. Revue Internationale des Sciences Appliquées. 2 (02), , 01-13. ISSN-1840-8869

[38] Minkova S. Technology for production of low viscosity drinking yogurt. Bulgarian Journal of Agricultural Science. 2001.

[39] Tchekessi C, Bokossa A, Agbangla C, Azokpota P, Daube G, Scippo ML, Bokossa IY. Production and microbiological evaluation of three types of" Dèguè", a local fermented drink made from milk in Benin. International Journal of Multidisciplinary and Current Research. 2014; 2: 714-720.

[40] Houinssou RF, Adjou ES, Ahoussi ED, Sohounhloué DC, Soumanou MM. Biochemical and sensorial Characteristics of cowpea (Vigna unguiculata) stored with essentials oils extracted from plants of Myrtaceae family. International Journal of Innovation and Applied Studies. 2014; 9(1): 428.

[41] Castañón LE. Saveurs et sensations de l'Afrique chez Calixthe Beyala. LyCE Estudios. $2012 ; 9$.

[42] Hounhouigan JD, Kayode AP, Bricas N, Nago MC. Les caractéristiques culinaires et organoleptiques des ignames recherchées en milieu urbain au Bénin. 2003.

[43] Newilah GN, Tchango JT, Fokou É, Etoa FX. Processing and food uses of bananas and plantains in Cameroon. Fruits. 2005; 60(4): 245-253.

[44] Videgla EG, Floquet A, Mongbo R, Garba K, Tossou HS, Toukourou F. Liens à l'origine et qualité spécifique d'un produit de l'artisanat agroalimentaire du Bénin-le kluiklui d'Agonlin. Cahiers Agricultures. 2016; 25(3): 35003.

[45] Camara MA, N'goran-Aw ZEB, Cissé M, Elleingand EF, Assidjo NE. Evaluation de la consommation des cultures locales dans le centre-nord de la Côte d'Ivoire: Cas de l'igname, du manioc et de l'arachide. International Journal of Innovation and Applied Studies. 2018; 24(4): 1782-1793.

[46] Braddock JC, Sims CA, O'keefe SF. Flavor and oxidative stability of roasted high oleic acid peanuts. Journal of Food Science. 1995; 60(3): 489-493.

[47] www.lesgourmandisesdekarelle.com

[48] Watson N. Premium nougat in South Africa-Neil Watson meets Mark Sack of Sally Williams Fine Foods, manufacturer of premium honey nougat. Confection. 2006; 29-32.

[49] Oduro I, Ellis WO, Dziedzoave NT, Nimako-Yeboah K. Quality of gari from selected processing zones in Ghana. Food Control. 2000; 11(4): 297-303.

[50] Chukwuji CO, Inoni OE, Ike PC. (2007). Determinants of technical efficiency in gari processing in Delta State Nigeria. Journal of Central European Agriculture. 2007; 8(3): 327-336.

[51] Edema MO, Atayese AO, Bankole MO. Pure water syndrome: bacteriological quality of sachet-packed drinking water sold in Nigeria. African Journal of Food, Agriculture, Nutrition and Development. 2011; 11(1).

[52] Okorafor KA, Eleng IE, Ogah JO. Tests of quality of some products of sachet water in Ogoja, Cross River State, Nigeria. ARPN J Sci Technol. 2014; 4: 647-653.

[53] Mahale DP, Khade RG, Vaidya VK. Microbiological analysis of street vended fruit juices from Mumbai city, India. Internet Journal of Food Safety. 2008; 10(9): 31-34.

[54] Canet C, N'Diaye C. L'alimentation de rue en Afrique. FNA/ANA. 1996; 17(18): 4-13.

[55] Tidjani, A., Agassounon, D. T. M., Ameyapoh, Y., Toukourou, F., \& Souza, C. (2007). Essais de conservation des viandes sechees «kilichi» commercialisees au tchad: etudes de la stabilite microbiologique. Journal de la Recherche Scientifique de l’Université de Lomé, 9(1). 
[56] Omodara NB, Obijole AO, Adekunbi EA, Oloyede HO, Oyebade A. Investigation of polycyclic aromatic hydrocarbon concentration in roasted plantain, roasted meat and smoked fish in Ondo. Nigeria. Int J Innov Environ Stud Res. 2015; 3(1): 27-31.

[57] University of California - Los Angeles. Study reveals how long COVID-19 remains infectious on cardboard, metal and plastic: People may acquire coronavirus through air and by touching contaminated surfaces. ScienceDaily. 2020. 